\begin{tabular}{|c|c|c|}
\hline $\begin{array}{l}\text { (1) } \\
\text { SiiRT } \\
\text { ÜNIVERSTIESi }\end{array}$ & $\begin{array}{c}\text { Türkiye Tarımsal Araştırmalar Dergisi } \\
\text { dergipark.org.tr/tutad }\end{array}$ & $\begin{array}{l}\text { Turk J Agric Res } \\
\text { 2021, 8(3): 301-310 } \\
\text { ○ TÜTAD } \\
\text { ISSN: 2148-2306 } \\
\text { e-ISSN: 2528-858X }\end{array}$ \\
\hline $\begin{array}{l}\text { UNIVERSIIIESI } \\
\text { Bulimin Fiüunda }\end{array}$ & Research Article & doi: $10.19159 /$ tutad.987841 \\
\hline
\end{tabular}

\title{
Searching Alternative Uses of Grassland for Sustainable Development: Evidence from the Eastern Black Sea Region, Turkey
}

\author{
İsmet BOZ ${ }^{*}$, Adem KAMALAK ${ }^{2}$, Osman KILIÇ ${ }^{1}$, Çağrı Özgür ÖZKAN ${ }^{2}$ \\ ${ }^{1}$ Ondokuz Mayls University, Faculty of Agriculture, Department of Agricultural Economics, Samsun, TURKEY \\ ${ }^{2}$ Kahramanmaraş Sütçü İmam University, Faculty of Agriculture, Department of Animal Science, Kahramanmaraş, TURKEY
}

\begin{tabular}{l}
\hline Received: $27.08 .2021 \quad$ Accepted: 07.12 .2021 \\
\hline ORCID ID (By author order) \\
(D) orcid.org/0000-0001-7316-9323 (Dorcid.org/0000-0003-0967-4821(Dorcid.org/0000-0002-0129-4034 (D)orcid.org/0000-0003-1752-8293 \\
"Corresponding Author: ismet.boz@omu.edu.tr
\end{tabular}

\begin{abstract}
Sustainably utilizing natural resources would provide sustainable livelihoods for agrarian communities in developing countries. Using alternative and more efficient methods to utilize natural resources will probably serve to achieve this goal. Ensiling grass in the Eastern Black Sea Region of Turkey is assumed to provide an alternative roughage fodder source for the animal husbandry sector which has faced dramatic declines for the last decades. This study investigated the possibilities of preparing and adopting grass silage in the region where drying grass to provide roughages for winter feeding is troublesome due to the heavily rainy climate during the harvest season. The study was organized in two broad sections; (1) socioeconomic survey and (2) ensiling process for roughage fodder provision. In the first section, socioeconomic characteristics of livestock farmers, farming practices applied, problems encountered by farmers, and awareness level about grass silage in the region were investigated. In the second section, a silage preparation process was carried out by (1) harvesting and ensiling of grass, (2) determination of the composition of grass silages, and (3) determination of aerobic stabilities of silages. Results showed that livestock farmers in the region have small numbers of animals and operate conventionally, farmers tend to be older, hold an elementary school degree, and are mostly not open to innovations. They face serious problems with drying their grass to provide roughage fodders and lack information about this technology. The ensiling process revealed favorable results that grass produced in the region can be successfully turned into silage. The quality can further be increased with some additives. The study concludes that to sustainably utilize the regional grasslands, awareness-raising campaigns and extension programs for ensiling technology should be organized.
\end{abstract}

Keywords: Sustainable development, grass silage, ensiling, adoption of innovations, technology adoption, regional development

\section{Introduction}

Sustainable development of rural areas and the farming sector largely depends on the utilization of challenging geographical features of a region. Among these features in the Black Sea Region of Turkey, are the abundant and highly fertile grasses in the uphill and mountainous areas but hard to dry for providing roughage for winter feeding due to lack of sunny days during the harvest season of the July-August period. Hundreds of thousands of farmers have been living in these areas and making their lives with rearing livestock grazed in the pastures from late spring to late autumn, and fed with dry roughages and concentrates in winter
(Yavuz et al., 2008). For this reason, providing dry forages from their grassland is a very troublesome activity for farmers who struggle to stay in business with their on-farm inputs.

Dealing with challenging natural conditions has become difficult for the Blacksea peasants day by day, and many of them have migrated to large cities. The annual net migration rate from the region was minus $1.26 \%$ for the last decade. Migration to other regions was so much that the proportion of those originally from the region but living outside the region reached $51.6 \%$ for Trabzon province, $61.2 \%$ for Rize province, $63.7 \%$ for Giresun province, and $70.1 \%$ for Ordu province (Anonymous, 2021). On 
the other hand, the migration from the villages to the cities within the region is even faster due to employment opportunities for adults, better education conditions for the youth, and other social and economic facilities for families that big cities have to offer. Since recent trends and developments have shown that young people have dramatically lost their interest in living in rural areas and dealing with agricultural activities, farming, and other nonfarm livelihoods in rural areas have become more and more done by the old population.

Alternative use of regional resources may create opportunities for sustainable livelihoods in rural areas and may increase the value of renewable resources which will make significant contributions to sustainable development. One of the alternatives in the eastern Black Sea Region of Turkey is assumed to be ensiling grass to process it to an alternative roughage feed for winter use. As a result of severe weather conditions, fodder supply shortages in the winter and early spring seasons are commonly encountered, particularly in February and April during which grazing is impossible due to the overwhelming majority of grazing lands being covered by snow. Presently ensiling practice from grassland has no use in the region and is assumed to be an innovation which is defined as an idea, practice, or object that is perceived as new by an individual or other unit of adoption (Rogers, 2010). Adoption of agricultural innovations may reduce production costs, save labor, and play a key role in increasing the quality and quantity of agricultural production. Using new technologies at the farm level can be assumed to be the adoption of innovations that increase the competitive power of farmers over their counterparts operating in other regions. Grass silage technology can be considered as an innovation, particularly for the livestock farmers operating in the Eastern Black Sea region of Turkey (Boz et al., 2016; Yildirım et al., 2016, 2017; Boz and Kılıç, 2020).

Silage is a forage obtained by fermenting waterrich crops by leaving them to the activity of lactic acid bacteria in an airless atmosphere in a silo container prepared from concrete, stone, wood, or plastic material. In other words, a kind of pickle prepared from water-rich crops for animals (Kutlu, 2013). Especially in the shortage of green forage, it is prepared to meet the needs of quality roughage for animals. Ensiling increases the digestibility of the feed, protect it for a long time without compromising the quality, saves space, and provides high-quality roughage feed at a cheap price (Bilal, 2009).

It is a generally accepted fact that animal products are very important in terms of the balanced and adequate nutrition of human beings. A wellbalanced diet must be prepared with concentrates and roughages to meet the nutritional requirements of ruminant animals (Kutlu, 2013). Feed costs, which account for about $70 \%$ of the costs incurred during the production phase of ruminant products, significantly affect the profitability of the business. In this respect, roughages that are both relatively cheap and affect the digestive activities of ruminants positively affect business performance (Garipoğlu, 2014; Anonymous, 2015).

Meeting the green forage requirements of animals is limited due to climatic and geographical conditions. During the vegetation periods, the excess amount of green forages given to animals by harvesting cannot be maintained for a long time due to their water contents. To prevent deterioration, the water-rich crops must be properly stored until they are used with the help of various methods, one of which is the ensiling process (Kutlu, 2013).

Although there are many types of roughage sources, their use in Turkey is mostly limited to hay, alfalfa, vetch, and maize. However, in many other countries, especially in developed countries, very different roughage sources (sunflower silage, wheat silage, ammonia-added straw, urea-added straw, and apple pomace) are used. A significant portion of these crops are cultivated in Turkey but they are not economically utilized for fodder production (Garipoğlu, 2014). Although grass is also a significant source of forage that can be processed to silage, this method has no common use by farmers in Turkey. However, research in different countries showed that grass can successfully be processed to silage which provides cheap and nutritious roughage fodder for livestock (Vranic et al., 2009; Carvalho et al., 2010; Castro et al., 2010; Rego et al., 2010; Güven, 2011; Genever, 2013). Research showed that 800-2000 meters altitude of Trabzon province (approximately the middle point of the research area) are rich in forage species of Agrostis capillaris ssp. capillaris, Briza media, Brachybodium pinnatum, Dactylis glomerata, Holcus lanatus, and Poa pratensis. Forage legumes include Coronilla varia, Coronilla orientalis, Lotus corniculatis, Lathyrus laxiflorus, Trifolium pratense, Trifolium medium Trifolium resupinatum, Trifulium repense, Medicaco rupulina, Onobrychis armena, and Vicia cracca (Reis et al., 2004). Because a large variety of forage crops are grown in the research area, and the region offers a significant impact on forage silage, there is a need for determining if these crops can scientifically be used for this purpose. The study also examines the reasons for farmers not using this practice in the eastern Black Sea Region of Turkey. 
The primary purpose of this study was to determine the possibilities of preparing and using grass silage to provide roughage fodders for livestock farmers operating in the uphill and mountainous lands of the Eastern Black Sea Region of Turkey. The specific objectives include the following:

(1) Determine socioeconomic characteristics of livestock farmers.

(2) Describe farming practices applied by the livestock farms in the region.

(3) Determine problems encountered by livestock farmers and the awareness level of grass silage in the region.

(4) Determine the quality and some characteristics of grass silages

(5) Describe possible contributions that grass silage will make to the livestock farmers and sustainable development in the region.

Research results are expected to provide useful information for all stakeholders involved in the rural developmental process in the region. Successfully ensiling grass samples will make it possible for farmers to prepare cheap and nutritious roughage fodders. Results of the socio-economic survey will provide information about the farming system in the region, problems encountered by farmers, the awareness level of farmers about grass silage, and strategies to be followed for the adoption and diffusion of this technology.

\section{Materials and Methods}

\subsection{Socioeconomic survey}

The target population for the socioeconomic survey was defined as smallholder livestock farmers living in the Eastern Black Sea Region provinces of Ordu, Giresun, Trabzon, and Rize. Initially, two districts from each province (total eight districts) and three villages from each district (total twenty-four villages) were selected based on the criteria of agricultural potential, proximity to the city center, socioeconomic characteristics of rural communities, and potential of livestock production in the villages. From each village, a list of smallholder cattle owners showing their number of cattle was obtained from the district offices of the Ministry of Agriculture and Forestry. These made the accessible population of this study. Considering frequency distributions of the number of animals farmers owned, the accessible population was divided into three strata with 1-5 animals, 6-10 animals, and more than 10 animals. Yamane's (2001) stratified sample size determination formula (Equation 1) was used to determine sample size.

$$
n=\frac{N \sum N_{h} S_{h}^{2}}{N^{2} D^{2}+\sum N_{h} S_{h}^{2}}, D^{2}=\frac{e^{2}}{t^{2}}
$$

In this formula; $\mathrm{n}=$ sample size, $N=$ accessible population, $N_{h}=$ number of farmers in a stratum, $S_{h}=$ standard deviation within a stratum, $D^{2}=$ desired variance, $e=$ accepted error from the mean, and $t=\mathrm{t}$ value corresponding to the accepted confidence interval.

Accepting a 5 percent error from the mean $(e)$ and 95 percent confidence interval $(t=1.645)$, the sample size was calculated as 278 . This number was proportionally distributed to three strata, and respondents from each stratum were randomly selected.

Data were collected by conducting face-to-face interviews with farmers during which a questionnaire was administered. It was included two sections, the first section included questions about the socioeconomic characteristics of the respondents while the second section included questions related to present farming systems in the region and adoption possibilities of grass silage. Technically the questionnaire included both openended and closed-ended questions. Two studies (Boz et al., 2011; Budak et al., 2012) were taken into consideration in the preparation of this questionnaire. Questions related to socioeconomic characteristics of farmers were mostly modified from Rogers (2010) and questions related to farming practices were mostly modified from Budak et al. (2012). Respondents' opinions and comments were noted for the open-ended questions. Data were collected in March and April 2015.

Descriptive statistics including frequencies, percentages, means, and standard deviations were used to analyze quantitative variables. Socioeconomic characteristics and farm-level practices were analyzed in this way and Table 1 and Table 2 were developed for this purpose. During the data collection process, many notes were taken by the researcher from the respondents' comments on a given issue related to their farming system. If many farmers were concerned about similar problems and made comments accordingly, these were also considered in the data analysis process.

\subsection{Ensiling process}

Harvesting and ensiling of grass: In September 2014, grass at the flowering stage were harvested from each village and cut in 1-3 cm sizes with grass cutting machine. Then, the chopped grass was filled and compressed in $2 \mathrm{~kg}$ of high-quality airtight plastic boxes and ensilaged for 60 days. Ensiling was organized as three replications in each district (Total 24 samples). 
Table 1. Socioeconomic characteristics of farmers*

\begin{tabular}{|c|c|c|c|c|c|}
\hline Variables & $\mathrm{N}$ & $\%$ & Variables & $\mathrm{N}$ & $\%$ \\
\hline Age of farmer & & & \multicolumn{3}{|l|}{ Having hybrid breeds of cows } \\
\hline$<35$ & 23 & 8.3 & Yes & 194 & 69.8 \\
\hline $35-50$ & 91 & 32.7 & No & 84 & 30.2 \\
\hline$>50$ & 164 & 59.0 & Total & 278 & 69.8 \\
\hline Total & 278 & 100.0 & \multicolumn{3}{|l|}{ Having indigenous breeds of sheep } \\
\hline \multicolumn{3}{|l|}{ Level of education } & Yes & 10 & 3.6 \\
\hline Illiterate & 8 & 2.9 & No & 268 & 96.4 \\
\hline Literate, no degree & 17 & 6.1 & Total & 278 & 100.0 \\
\hline Primary school & 132 & 47.4 & Average number of livestock & $\mathrm{x}$ & sd \\
\hline Secondary school & 73 & 26.3 & Hybrid cows & 3.24 & 5.32 \\
\hline High school & 35 & 12.6 & Indigenous cows & 0.74 & 2.18 \\
\hline College & 13 & 4.7 & Improved cows & 0.50 & 3.18 \\
\hline Total & 278 & 100.0 & Indigenous sheep & 1.88 & 12.72 \\
\hline Membership of farmer & & & \multicolumn{3}{|c|}{ Use of long-term loans for farm investments } \\
\hline Member & 69 & 24.8 & Yes & 57 & 20.5 \\
\hline Not member & 209 & 75.2 & No & 221 & 79.5 \\
\hline Total & 278 & 100.0 & Total & 278 & 100.0 \\
\hline \multicolumn{3}{|c|}{ Participation in village administration } & \multicolumn{3}{|l|}{ Annual income } \\
\hline Yes & 76 & 27.3 & $<20.000$ & 69 & 24.8 \\
\hline No & 202 & 72.7 & $20.000-30.000$ & 76 & 27.4 \\
\hline Total & 278 & 100.0 & $31.000-40.000$ & 62 & 22.3 \\
\hline \multicolumn{3}{|l|}{ Amount of land } & $40.000<$ & 71 & 25.5 \\
\hline No land & 8 & 2.9 & Total & 278 & 100.0 \\
\hline$<5 \mathrm{da}$ & 62 & 22.4 & \multicolumn{3}{|l|}{ Tractor ownership } \\
\hline $5-10 \mathrm{da}$ & 66 & 23.7 & Yes & 9 & 3.2 \\
\hline $11-20 \mathrm{da}$ & 71 & 25.5 & No & 269 & 96.8 \\
\hline $20<$ & 71 & 25.5 & \multicolumn{3}{|l|}{ Total } \\
\hline Total & 278 & 100.0 & \multicolumn{3}{|c|}{ Can you change your future by your own effort } \\
\hline \multicolumn{3}{|l|}{ Social security } & Yes & 47 & 16.9 \\
\hline No social security & 36 & 12.9 & Partly & 68 & 24.5 \\
\hline Bağ-Kur & 99 & 35.7 & No & 163 & 58.6 \\
\hline SSK & 128 & 46.0 & Total & 278 & 100.0 \\
\hline Green card & 8 & 2.9 & Farming experience & 14 & 5.0 \\
\hline Emekli Sandigi & 7 & 2.5 & $<10$ years & 27 & 9.7 \\
\hline Total & 278 & 100.0 & $10-20$ years & 37 & 13.3 \\
\hline \multicolumn{3}{|c|}{ Having improved breeds of cows } & $21-30$ years & 58 & 20.9 \\
\hline Yes & 30 & 10.8 & $30<$ years & 156 & 56.1 \\
\hline No & 248 & 89.2 & Total & 278 & 100.0 \\
\hline Total & 278 & 100.0 & \multicolumn{3}{|l|}{ Income level among all farmers } \\
\hline \multicolumn{3}{|c|}{ Having indigenous breeds of cows } & Low & 109 & 39.2 \\
\hline Yes & 59 & 21.2 & Medium & 155 & 55.8 \\
\hline No & 219 & 78.8 & High & 14 & 5.0 \\
\hline Total & 278 & 100.0 & Total & 278 & 100.0 \\
\hline
\end{tabular}

Determination of the composition of grass silages: At the end of the 60 day ensiling period, grass silages from each district were analyzed for dry matter (DM), crude ash (CA), crude protein (CP), and ammonia. To determine the DM contents of the silages, the product was dried at $105^{\circ} \mathrm{C}$. The silage samples were burned in the ash furnace at $525{ }^{\circ} \mathrm{C}$ for 4 hours for crude ash content. The Kjeldahl Method was used to determine the content of nitrogen $(\mathrm{N})$. The $\mathrm{CP}$ was calculated by the formula of $\mathrm{N} \times 6.25$ (Anonymous, 1990). The $\mathrm{pH}$ of the silages was determined as soon as the samples were collected with an electronic $\mathrm{pH}$ meter with a digital precision of 0.01 . Ammonia nitrogen of the silages $\left(\mathrm{NH}_{3} \mathrm{~N}\right)$ was determined by using the method developed by Weinberg et al. (2002).

One of the most common methods used to determine the silage quality practically is the Fleig score (FS), which is determined by using the relationship between the $\mathrm{DM}$ content and $\mathrm{pH}$ value of silage. FS was calculated using Equation 2 (Anonymous, 1987).

$$
\mathrm{FS}=[220+(2 \times \mathrm{DM}-15)]-40 \times \mathrm{pH}
$$


Table 2. Farm level practices

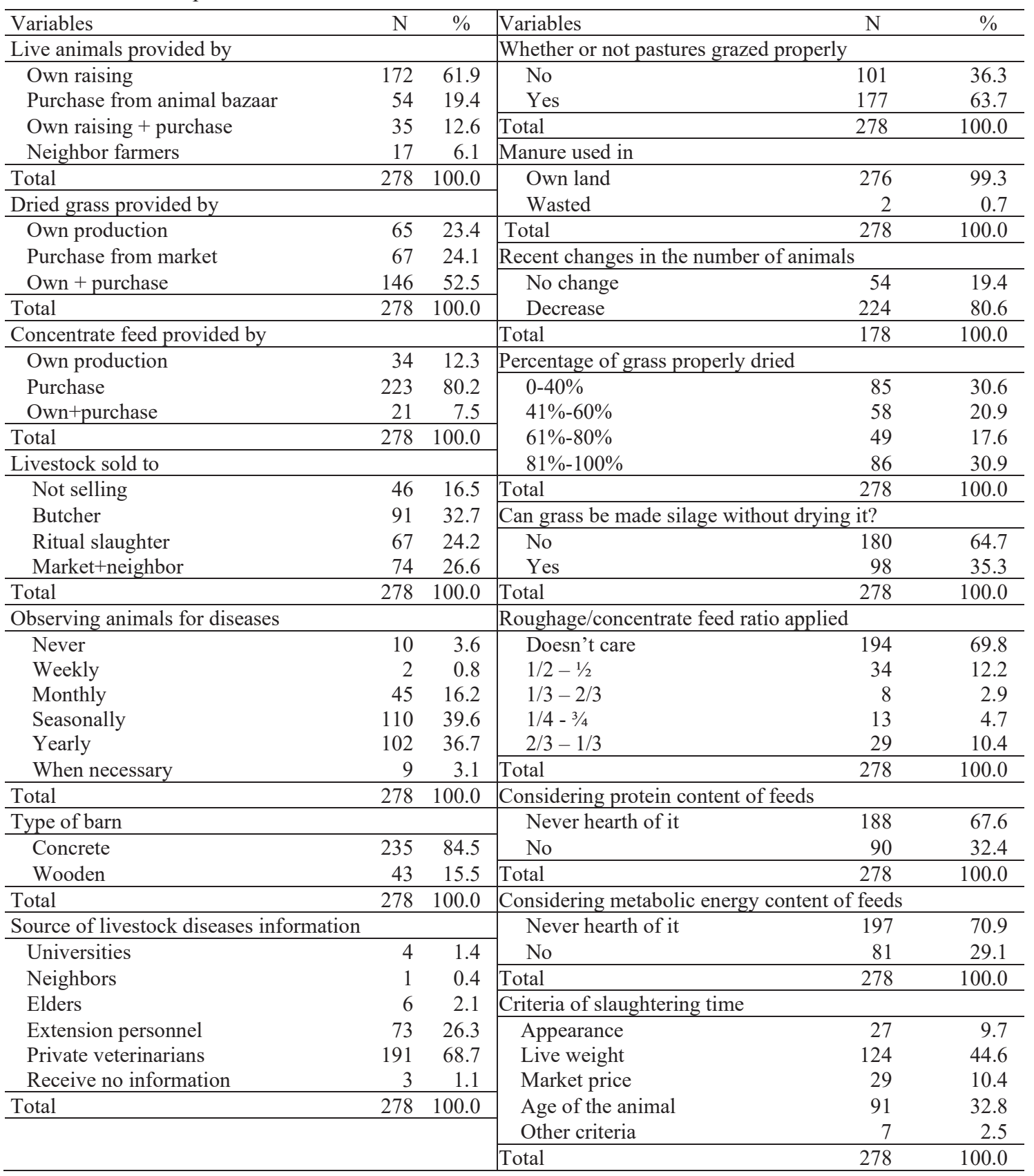

Considering the FS values obtained from the above-mentioned equation, the silage quality class (81-100: Very good, 61-80: Good, 41-60: Satisfactory, 21-40: Low, and 0-20: Bad) was evaluated (Anonymous, 1987).

Determination of aerobic stabilities of grass silages: Aerobic stability is defined as the time required for the silage material temperature to exceed the ambient temperature above $2{ }^{\circ} \mathrm{C}$ after contact with air at the end of the airtight period (Kung et al., 2000). The aerobic stability of the silage material was determined by temperature probes (TMC6-HD). In this method, the temperature change after the air contact of the silage material was recorded every hour and loaded into the data loggers. Then, these data were transferred to the computer to determine the aerobic stability of the silage materials.

\section{Results and Discussion}

\subsection{Socioeconomic characteristics of farmers}

The socioeconomic characteristics of the respondents are presented in Table 1. Sixteen socioeconomic characteristics were considered. It can be seen that more than half of the respondents 
$(59.0 \%)$ were older than 50 years of age (Average age $=53.04$ years; $S D=12.84)$, approximately half of them $(47.4 \%)$ were elementary school graduates, $75.2 \%$ had no membership of farmers' unions, $27.3 \%$ participated in village administration. Approximately three-fourths $(74.5 \%)$ of the respondents had farmland less than 20 decares (Average land size $=21.11$ decares; $\mathrm{SD}=25.37$ ). A large majority (87.9\%) had social security, $70.5 \%$ didn't use credit for inputs, $79.5 \%$ didn't use bank loans for investments. Small percentage of farmers had improved breeds of cows $(10.8 \%)$ and indigenous cows $(21.2 \%)$ while those who had hybrid breeds of cows were $69.8 \%$, and indigenous breeds of sheep $3.6 \%$. The average numbers of livestock an average farmer in the region owns were 3.24 hybrid cows, 0.74 indigenous cows, 0.50 improved breeds of cows, and 1.88 indigenous sheep. Less than half of the respondents (45.1\%) had an annual income higher than 40 thousand Turkish liras, and no farmer had a tractor due to geographical conditions of landscape in the region. More than half of the respondents $(58.6 \%)$ believed that they cannot change their future with their effort, $56.1 \%$ had a farming experience of more than 30 years, and $55.8 \%$ considered themselves in the medium income level category considering their counterparts in their village.

\subsection{Farm-level practices}

Table 2 presents the selected farming practices applied by small-holder livestock owners in the region. It can be followed that more than half of the respondents $(61.9 \%)$ raised their livestock while the remaining part purchased them from the animal bazaar and neighboring farmers. Only 23.4\% provided the entire dry grass from their land indicating that the dependency on off-farm dry grass is quite high. This ratio goes even lower $(12.3 \%)$ with concentrated feeds which further increases the dependency on off-farm inputs (Table 2). Because of unfavorable climatic conditions and inadequate mechanization, grain cereals that are processed to concentrated feeds cannot be economically cultivated in the region.

Almost one-third of the respondents (32.7\%) sold their cattle to butchers while almost one-fourth $(24.2 \%)$ of them to neighbors and animal bazaars. Those who observed their animals for diseases and other problems on a seasonal basis were $39.6 \%$ while those who used the same practice annually were $36.7 \%$. The types of the barn were $84.5 \%$ concrete and $15.5 \%$ wooden made. The most important criterion in deciding to sell animals for slaughter was the live weight $(44.6 \%)$ and age of the animal $(32.8 \%)$. The majority of the respondents $(63.7 \%)$ thought that grassland around their villages were grazed properly by small-holder livestock farmers. Almost all respondents (99.3\%) utilized manure by putting it on their land (Table 2).

A large majority (80.6\%) experienced a decrease in their livestock numbers indicating income generating from animal husbandry and living conditions in rurality are getting worse. Only less than one-third $(30.9 \%)$ could properly dry 81 $100 \%$ of their harvested grass, the remaining farmers could dry at descending rate of their harvested grass. The majority of farmers $(64.7 \%)$ thought that grass cannot be ensilaged without completely drying it, indicating that awareness and information about the silage technology in the region are quite low. More than two-thirds (69.8\%) didn't care about roughage to concentrated feed ratio when feeding their herd, $67.6 \%$ never heard of the protein content of feeds, and $70.9 \%$ never heard metabolic energy content of feeds. Private veterinarians $(69.7 \%)$ were the most important source of animal diseases information for farmers (Table 2). Extension personnel, elders, universities, and neighbors, in descending order, were other sources of information.

\subsection{Problems encountered by farmers and reasons for not practicing grass silage}

Most of the small-holder livestock farmers in the research area stressed that the number of livestock has continuously decreased and young people had no interest in agriculture. The reasons for decreasing livestock in the region and problems associated with this decrease were asked to farmers during the data collection process. They stressed that the number of livestock has a decreasing trend in the region because of high feed prices, lack of family members to deal with animal husbandry, and low-income levels among farmers. In addition, lack of governmental support, illegal animal entries to the country, and lack of capital to purchase live animals are also effective factors.

Since farmers cannot properly dry their grass to produce roughage feeds for winter feeding because of severe climatic conditions and lack of sunny days during harvest seasons, feed shortages become inevitable and prices dramatically go up. Because the area has no favorable climatic conditions to produce dried roughages, they are purchased from other regions, which means that transportation costs further increase the price of roughages, particularly in winter seasons. This causes a downsizing in family farms as they are forced to sell some of their animals to purchase feeds for the remaining herds. The problems and difficulties experienced during providing roughage feed from their grassland were ranked as drying, harvesting, temporary storage in the field, transportation, and storage in the 
barnyard. All of these activities require human labor for which all family members are involved.

There are different reasons for farmers not adopting agricultural innovations. Determining these reasons would help policy-makers and extension practitioners to develop strategies for raising awareness and accelerating the adoption process. Since this study tried to determine the reasons for not practicing grass silage in the research area, the question regarding this purpose yields the following results. Almost half of the respondents $(46.8 \%)$ reported that they have never heard of practice of this type, while $23.4 \%$ reported that heard it but didn't have enough information to practice it. Almost one-fifth of the respondents $(19.4 \%)$ stated that they heard about grass silage but their farm conditions aren't suitable to practice it. Finally, a small percentage (10.4\%) of farmers heard it but they didn't believe that it would be a useful practice for their farm conditions.

\subsection{Analysis results of grass silage samples}

The composition, DM, CP, $\mathrm{NH}_{3}-\mathrm{N} / \mathrm{TN}, \mathrm{pH}$, and FS of pasture silages are given in Table 3. The DM content of silages ranged from $14.27 \%$ and $33.43 \%$. The highest DM content was obtained from the grass silage sample harvested in the Çaykara and Maçka districts while the lowest DM content was obtained from the grass silage sample of Gürgentepe district. As can be seen, the DM content of grass silage samples obtained from other districts except Maçka and Çaykara are very low, the silage materials must be wilted to some extent in the postharvest period to raise the DM content or the DM content must be increased with the additives with higher DM (Table 3).

The CP contents of grass silage ranged from 6.50 and $13.23 \%$ and the highest CP content was obtained from the Dereli and Gürgentepe districts and the lowest CP content was obtained for grass silage obtained from Kalkandere, Çamlıhemşin, and Maçka districts (Table 3). In particular, the silage obtained from these two districts had very low CP content, and therefore if they are used in ruminant diets, they should be supplemented with protein sources.

Silage ammonia contents ranged from 8.03 to $14.99 \%$. The highest ammonia content was found in the Gürgentepe district and the lowest ammonia content was found in the silages obtained from the districts of Dereli and Çaykara (Table 3). In general, ammonia contents are within normal limits. Silage $\mathrm{pH}$ values ranged from 4.59 to 5.46 and the lowest silage $\mathrm{pH}$ was found in the Çamlıhemşin and Çamaş districts and the highest was found in the silages obtained from the Çaykara district (Table 3). The
$\mathrm{pH}$ values of the silages obtained from the other districts except Çamaş were not found at the desired level possibly due to the low level of water-soluble carbohydrates in the ensilaged material. It is well known that lactic acid bacteria convert watersoluble carbohydrates to lactic acid during ensiling. Lactic acid is the most important acid that causes the $\mathrm{pH}$ of silage material to decrease.

The FS of the silages ranged from 32.43 to 61.45, and the highest FS was obtained for the silage prepared from the grass of the Maçka and Çamlıhemşin districts, while the lowest FS was obtained for the silage prepared from the grass of Dereli district (Table 3). Since the FS is calculated using the DM and $\mathrm{pH}$ of the silages, the high DM and low $\mathrm{pH}$ always cause the FS to be high (Eliş and Özyazıc1, 2019).

Aerobic stabilizations of grass silages produced in different districts are given in Figure 1. As can be seen, the grass silages produced in Çamlıhemşin district were spoiled first, followed by grass silages produced from the districts of Gürtentepe, Güce, Çamaş, and Kalkandere. No deterioration was observed in the silages produced from Maçka and Çaykara districts. Generally, the silages spoiled between 14 and 27 hours except for the silage obtained from the Çamlıhemşin district (Figure 1).

As a result, when evaluated in terms of color, structure, and smell, the silages were found of good quality. However, according to chemical analyzes and FS, the silages obtained from all districts were of medium and satisfactory quality. Therefore, to obtain higher quality silage in the future, the DM content of the silage material should be increased. In addition, water-soluble carbohydrate-rich additives should be added to the silage material to further synthesize enough lactic acid to lower the $\mathrm{pH}$ of silage. Earlier research showed that rich additives increase the quality of grass silages (Kung et al., 2000; Arslan and Essiz, 2009; Bilal, 2009; Bingöl et al., 2009; Rego et al., 2010; Güven, 2011). Silage additives are substances including enzymes or microorganisms, intended to be incorporated into silage to achieve desired fermentation (Anonymous, 2012). Proper use of additives and managing ensiling process increase silage quality, increase dairy cow performance, and the safety and quality of dairy products as well as animal and human health (Queiroz et al., 2018). Thus, to further increase the quality of grass silage of the region, the above procedure may be applied before initiating promotion programs for this technology.

\subsection{Feasibility of the ensiling method}

The feasibility of the ensiling method is evaluated in terms of cost and technical difficulty. 
Table 3. Composition, $\mathrm{pH}$, and Flieg scores of grass silages from different districts ${ }^{*}$

\begin{tabular}{lcrrrr}
\hline Districts & DM & CP & NH3-N/TN & pH & \multicolumn{1}{c}{ FS } \\
\hline Güce & $18.78^{\mathrm{bc}}$ & $11.58^{\mathrm{b}}$ & $10.06^{\mathrm{bc}}$ & $5.12^{\mathrm{b}}$ & $37.63^{\mathrm{bcd}}$ \\
Dereli & $18.18^{\mathrm{bc}}$ & $13.23^{\mathrm{a}}$ & $8.40^{\mathrm{c}}$ & $5.22^{\mathrm{ab}}$ & $32.43^{\mathrm{d}}$ \\
Gürtentepe & $14.27^{\mathrm{d}}$ & $12.72^{\mathrm{a}}$ & $14.99^{\mathrm{a}}$ & $4.96^{\mathrm{bc}}$ & $34.88^{\mathrm{cd}}$ \\
Çamaş & $16.03^{\mathrm{cd}}$ & $10.32^{\mathrm{c}}$ & $12.97^{\mathrm{ab}}$ & $4.60^{\mathrm{c}}$ & $52.94^{\mathrm{ab}}$ \\
Maçka & $31.95^{\mathrm{a}}$ & $7.31^{\mathrm{e}}$ & $10.17^{\mathrm{bc}}$ & $5.18^{\mathrm{ab}}$ & $61.45^{\mathrm{a}}$ \\
Çaykara & $33.43^{\mathrm{a}}$ & $8.58^{\mathrm{d}}$ & $8.03^{\mathrm{c}}$ & $5.46^{\mathrm{a}}$ & $53.46^{\mathrm{ab}}$ \\
Kalkandere & $19.88^{\mathrm{b}}$ & $6.55^{\mathrm{e}}$ & $9.06^{\mathrm{bc}}$ & $4.84^{\mathrm{bc}}$ & $51.03^{\mathrm{bc}}$ \\
Çamlıhemşin & $20.00^{\mathrm{b}}$ & $6.50^{\mathrm{e}}$ & $10.69^{\mathrm{bc}}$ & $4.59^{\mathrm{c}}$ & $61.27^{\mathrm{a}}$ \\
\hline ASE & 0.836 & 0.303 & 1.135 & 0.122 & \\
\hline SL & $* * *$ & $* * *$ & $* * *$ & $* * *$ \\
\hline
\end{tabular}

${ }^{*}:$ No difference in the means having the same superscript in the same column ( $\left.>00.05\right), \mathrm{NH}_{3}-\mathrm{N} / \mathrm{TN}$ : Proportion of ammonium nitrogen to total nitrogen (\%), ASE: Average standard error, SL: Significance level, ${ }^{* * *}: \mathrm{p}<0.001$

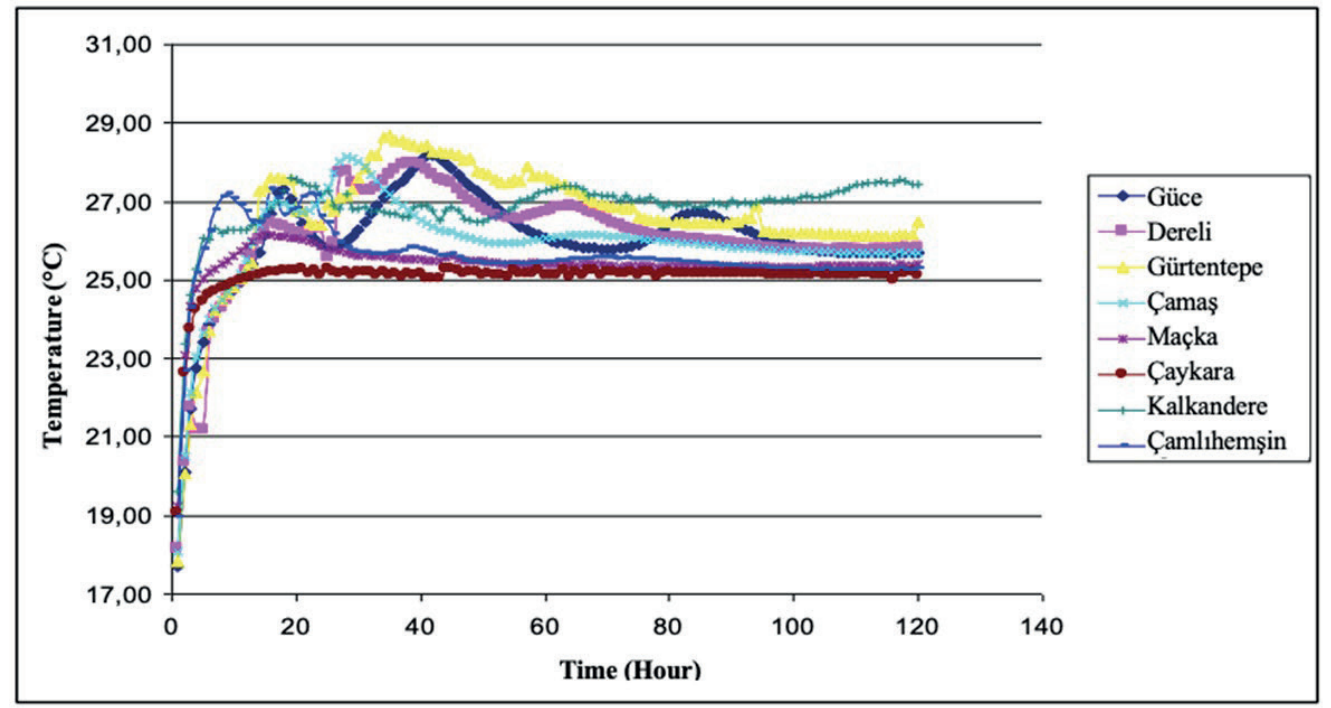

Figure 1. Aerobic stability of grass silages produced in different districts ${ }^{*}$

*: If the temperature of the silage exceeds the ambient temperature $\left(25^{\circ} \mathrm{C}\right)$ by $2{ }^{\circ} \mathrm{C}$, it is considered that the silage is spoiled. Therefore, the ambient temperature was $25^{\circ} \mathrm{C}$ and is kept constant during the experiments using refrigerated incubator.

Cost items of the ensiling process include raw material (forage crops harvested from farmers' fields or rental grasslands), $100-200 \mathrm{Kg}$ plastic storage silos, additives (if used), small or medium size grass chopper machine, and labor. The number of storage silos depends on the number of livestock and the quantity of forage crops harvested. If a farmer owns 5 dairy cows and decides to make 2000 $\mathrm{Kg}$ silage from his grassland, he needs 10 silos with $200 \mathrm{Kg}$ capacity and a small size grass chopper machine. Since there are no employment opportunities other than farming in the region the opportunity cost of labor is assumed to be zero. This means if farmers decide not to make silage they cannot earn any income in other activities with the labor force they would devote to silage making. Therefore, assuming the farmers harvested forages from their land and used their labor, the total costs of the ensiling process in the data collection period were approximately 4000 Turkish Liras (2000 TL the grass chopping machine and 2000 TL the silos).
This amount consisted of approximately $11 \%$ of an average farmers' yearly income and can easily be undertaken.

\section{Conclusions}

Sustainably utilizing regional resources is essential for sustainable development, particularly for developing countries. Grasses in the Eastern Black Sea Region of Turkey have enormous potential to make contributions to sustainable development via processing it to silage and providing roughage fodder for small-holder livestock farmers.

Possibilities of preparing silage from the grass of the Eastern Black Sea region of Turkey, the adoption level of this technology among farmers, and possible contributions it will make to sustainable development in the region were investigated by this study. A general profile of the farmer in the region was approximately a fifty years aged male farmer holding an elementary school 
degree. He has a low tendency of becoming a member of a farmers' organization as well as participating in village administration. He owns an average land of 21 decares, 1.20 improved breeds of cows, 4.72 hybrid cows, 0.31 indigenous cows, and 6.34 indigenous sheep. He is covered by a social security system which will provide him a certain amount of monthly income after retirement. He has a low tendency of using credit for inputs and bank loans for farm investments. His yearly income is about 20 thousand Turkish liras $(\$ 3,294$ as of September 30, 2018). He doesn’t have a tractor, and his farming experience is more than 20 years. With this average profile, it seems difficult for him to continue farming and to enjoy rural family life. However, employment opportunities in the other sectors of the economy are limited and most of these sectors employ highly skillful and talented personnel. For this reason, long-term measures and new approaches to improve livestock farmers' economic conditions are necessary.

A traditional farming system prevails in the region. Farmers generally have a low interest in agricultural innovations. The most important reasons for this are the difficulties in the implementation of innovations due to challenging geographical conditions and the reluctance of farmers. Farming, with its present form, doesn't seem to be the future livelihood of many respondents. Although they aren't satisfied with their present economic conditions they are still thankful and worrying about less advantaged people living in other parts of the country.

Because of the unique geographical conditions of the region, there are many physical and infrastructural constraints to apply farm technologies. Limited and fragmented land parcels provide few opportunities for developing a sustainable farming system as compared with the regions without these restrictions.

Providing roughage fodders for animal husbandry is quite problematic, particularly in the winter seasons. Due to the rainy climate, it is hard to get their grass dried, and therefore farmers have to purchase fodder for the winter season when the price level dramatically goes up, particularly in the late winter and early spring. If farmers adopt grass silage technology it will be possible for them to produce cheaper and high-quality roughage fodder for their animals.

Technical analyses of grass silage samples collected from the region proved that the region has an opportunity of providing forage for livestock farmers. The quality of silage can further be increased by using some additives in the ensiling process. This means there is a possibility of producing high quality and cheap silage from the regional resources which will compensate forage shortages particularly in the late winter and early spring seasons, and reduce variable costs of livestock farmers. This will ultimately make contributions to their income and wellbeing in the long-term span. However, the results of this study showed that almost half of the participants of this study aren't aware of this technology. Therefore, the Ministry of Agriculture and Forestry should bring together all the stakeholders involved in the animal husbandry sector in the region, and develop an extension program to raise awareness and initiate an adoption process accordingly.

\section{References}

Anonymous, 1987. Bewertung von Grünfutter, Silage und Heu. - Deutsche Landwirtschafts-Gesellschaft (DLG), DLG Merkblatt 224, Frankfurt.

Anonymous, 1990. Official methods of analysis of the Association of Official Analytical Chemists. (15th Edn.), Vol. 1, Association of Official Analytical Chemists, Inc, Arlington, Virginia.

Anonymous, 2012. Additives and Products or Substances Used in Animal Feed. (https://www.efsa.europa.eu/ en/science/scientific-committee-and-panels/feedap), (Accessed: 18.01.2020).

Anonymous, 2015. Ensiling. (http://alivaizgaripoglu. com/wp-content/uploads/2015/03/silaj_yapimi.ppt), (Accessed: 01.02.2021). (In Turkish).

Anonymous, 2021. Migration Statistics. Turkish Statistical Institution, (http://www.tuik.gov.tr/Pre TabloArama.do), (Accessed: 18.06.2021).

Arslan, C., Essiz, D., 2009. Establishing the optimum cutting date and additives for pasture grass silage and its mycotoxin levels. Kafkas Üniversitesi Veterinerlik Fakültesi Dergisi, 5(4): 531-538.

Bilal, M.Q., 2009. Effect of molasses and corn as silage additive on the characteristics of mott dwarf elephant grass silage at different fermentation periods. Pakistan Veterinary Journal, 29(1): 19-23.

Bingöl, N.T., Bolat, D., Karsl1, M.A., Akça, İ., 2009. Effects of molasses addition into barley-sainfoin mixture at varying levels on silage quality and digestibility. Atatürk University Journal of Veterinary Sciences, 4(1): 23-30. (In Turkish).

Boz, I., Akbay, C., Bas, S., Budak., D.B., 2011. Adoption of innovations and best management practices among dairy farmers in the Eastern Mediterranean region of Turkey. Journal of Animal and Veterinary Advances, 10(2): 251-261.

Boz, İ., K1lıç, O., 2020. Reasons for grass silage not being adopted by livestock farmers in the Eastern Black Sea Region. Anadolu Journal of Agricultural Sciences, 35(3): 496-504. (In Turkish).

Boz, I., Yildirim, Ç., Turkten, H., 2016. Adoption and diffusion of grass silage in Trabzon province of Turkey. Advances in Ecological and Environmental Research, 1(1): 1-13. 
Budak, D.B., Boz, I., Akbay, C., Baş, S., 2012. Factors influencing selected innovations and best management practices among sheep farmers in the Eastern Mediterranean Region of Turkey. Journal of Animal and Veterinary Advances, 11(10): 1713-1718.

Carvalho, J.N., Pires, A.J.V., Veloso, C.M., Silva, F.F., Reis, R.A., Carvalho, G.G.P., 2010. Apparent digestibility of diet with elephant grass ensiled with different additives. Arquivo Brasileiro De Medicana Veterinaira De Zootecnia, 62(4): 889-897.

Castro, G.H.F., Rodrigez, N.M., Goncalves, L.C., Mauricio, R.M., 2010. Productivity, agronomical and nutritional traits of Tanzania grass cut on five different ages. Arquivo Brasileiro De Medicana Veterinaira Zootecnia, 62(3): 654-666.

Eliş, S., Özyazıcı, M.A., 2019. Determination of the silage quality characteristics of different switchgrass (Panicum virgatum L.) cultivars. Applied Ecology and Environmental Research, 17(6): 15755-15773.

Garipoglu, A.V., 2014. Alternative Roughage Sources in Dairy Cattle Nutrition. (http://docplayer.biz.tr/ 9931995-Sut-sigirlarinin-beslenmesinde-alternatifkaba-yem-kaynaklari.html), (Accessed: 12.02.2021). (In Turkish).

Genever, L., 2013. Making Grass Silage for Beter Returns. Beef And Sheep, BRB Manuals, (www.eblex.org.uk/.../brp_b_brpmanual5), (Accessed: 02.03.2021).

Güven, I., 2011. The use of honey locust pods as a silage additive for grass. PhD. thesis, Kahramanmaraş Sütçü İmam University, Institute for Graduate Studies in Science and Technology, Kahramanmaraş, Turkey. (In Turkish).

Kung, L.,Treacher, R.J., Nauman, G.A., Smagala, A.M., Endres, K.M., Cohen, M.A., 2000. The effect of treating forages with fibrolytic enzymes on its nutritive value and lactation performance of dairy cows. Journal of Dairy Science, 83(1): 115-122.

Kutlu, H.R., 2013. All Aspects of Silage Making and Silage Feeding. Çukurova University, Agriculture Faculty, Adana, Turkey. (In Turkish).

Queiroz, O.C.M., Ogunade, I.M., Weinberg, Z., Adesogan, A.T., 2018. Silage review: Foodborne pathogens in silage and their mitigation by silage additives. Journal of Dairy Science, 101(5): $4132-$ 4142.

Rego, M.M.T., Neiva, J.N.M., Do Rego, A.C., Candido, M.J.D., Clementino, R., Restle, J., 2010. Nutritional evaluation of elephant-grass silage with by product of annatto. Revista Brasileira De Zootecnia-Brazillian journal of Animal Science, 39(10): 2281-2287.

Reis, M., Gümüş, S., Ulu, F., 2004. A research on the yield potential and plant population similarity of the forest rangelands of Trabzon-Karadere Rainfall Basin. Eastern Blacksea Forestry Research Institute Journal of Research, 1: 60-74. (In Turkish).

Rogers, E., 2010. Diffusion of Innovations. The Free Press, A Division of Simon \& Schuster Inc. 1230, Avenue of the Americas New York.

Vranic, M., Knezevic, M., Perculia, G., Bosnjak, K., Leto, J., 2009. Intake, digestibility in vivo, $\mathrm{N}$ utilization and in sacco dry matter degradability of grass silage harvested at three stage of maturity. Asian-Australasian journal of Animal Sciences, 22(2): 225-231

Weinberg, Z.G., Ashbell, G., Hen, Y., Filya, I., 2002. The effects of temperature on the aerobic stability of wheat and corn silages. Journal of Industrial Microbiology and Biotechnology, 28: 261-263.

Yamane, T., 2001. Elementary Sampling Theory. Translators: A. Esin, C. Aydın, M.A. Bakır, E. Gurbuzsel, Literatur Yayıncılik, Istanbul, Turkey. (In Turkish).

Yavuz, T., Sürmen, M., Töngel, M.Ö., Çankaya, N., 2008. A research on grassland utilization habits in Black Sea Region. Reserach Journal of Agricultural Sciences, 1(1): 43-47. (In Turkish).

Yıldırım, Ç., Türkten, H., Boz, İ., 2016. Adoption characteristics of livestock farmers and their attitudes to silage making from grass in interior coastal areas of Rize province, Turkey. Custos E@gronegocio Online, 12(2): 138-155.

Yıldırım, Ç., Türkten, H., Boz, İ., 2017. Adoption characteristics of livestock farmers to making grass silage in Ordu province of Turkey. Custos E @gronegocio Online, 13(3): 172-181. 